\title{
NOTES
}

\section{WAGE EARNERS' PRIORITY IN BANKRUPTCY: APPLICATION TO WELFARE FUND PAYMENTS}

Section 64a(2) of the Bankruptcy Act grants a limited priority, in the distribution of bankrupt estates, to certain wage earner claims, thereby affording a unique protection to a class of creditors whose economic weakness is almost universally recognized. Although the term "wages" is not defined, its presence in the Act since 1898 has afforded some opportunity for judicial determination of its scope. Nevertheless, with the special emphasis being accorded fringe-benefit considerations in contemporary collective bargaining practices, ${ }^{2}$ a new dimension has been added to the concept of wages which suggests, perhaps, that its present

\footnotetext{
This provision grants priority to "wages and commissions not to exceed $\$ 600$ to each claimant, which have been earned within three months before the date of commencement of the proceeding, due to, workmen, servants, clerks, or traveling or city salesman on salary or commission basis." 66 STAT. 426 (1898), I I U.S.C. $\$$ 104 (a) (2) (1952). As amended, Pub. L. No. 840, 84th Cong., 2d SEss. §I (July 30, 1956).

For a résumé of legislative history and changes in $\$ 64$ see 3 CoLLIER, BankruPTCY \$64.01 (14th ed. 1940). See generally, Nadler, Bankruptcy Act Materially Overhauled, I5 GA. B. J. 178 (1952); Hefter, Lucky Thirteen: Wage Earner Plans Under the Bankruptcy $A c t, 29$ TuL. L. REv. 517 (1955); Nadler, Relief for the Wage Earner: " $A$ New Way to Pay for Old Debts," 60 CoM. L. J. 33 (1955); Griswold, Wage Earner Plan, is KY. S. B. J. I04 (1955).

$\therefore$ By the end of 1954 , twenty-nine million workers and their forty-six million dependents were covered, to some extent, by private welfare and pension funds in the area of welfare fund-type fringe benefits alone. The greatest expansion in the number of these programs has occurred since 1940 and, more especially, since 1 945. Approximately sixty percent of those covered by various types of welfare plans are involved in programs which have heen developed through collective bargaining processes. For specimen contracts see 4 P-H 1956 Union Contracts and Collective Bargaining Practice I56,000; 79 Monthly LaB. Rev. I j2, 812 (1956).

Social insurance, pensions and paid sick leave currently occupy the area of greatest interest in collective bargaining. In $195 \mathrm{I}$, only ten percent of contracts provided pensions and thirty percent provided social insurance benefits. Since that time, however, there has been a 350 percent increase in pensions and almost a 150 percent increase in social insurance. Almost three-fourths of all collective bargaining agreements now make some provision for any or all of the following forms of social insurance: life insurance, accidental death and dismemberment insurance, non-occupation sickness and accident insurance, hospitalization, surgical, medical, and maternity insurance.

Paid sick leave provisions, having decreased since 1950, appear in about sixteen percent of all contracts. The amount of paid leave and the duration of leave differ in various occupational fields. For a complete analysis of employee benefits achieved through collective bargaining see 2 BNA C.B.N.C. $44: 85$ I (1956).
} 
judicially-prescribed limitations should be re-examined. In this context, a recent district court decision is of particular significance.

In In the Matter of Sleep Products, Inc., ${ }^{3}$ a bankrupt employer was required, under the provisions of a collective bargaining agreement, to make monthly payments to a union welfare trust fund ${ }^{4}$ based on its gross monthly payroll. For the three-month period immediately preceding. bankruptcy the employer failed to pay the required amount, and the trustees of the fund, asserting a section $64 \mathrm{a}$ (2) wage priority, subsequently filed a claim for this unpaid sum. A motion by the trustee in bankruptcy to dismiss the claim was granted by order of the referee which, on appeal, was sustained by the district court.

The courts traditionally have narrowly confined the coverage of this particular section. Thus, the priority it confers has been generally extended only to the claims of those who have been employed in subordinate capacities; ${ }^{5}$ and, concomitantly, it has been withheld from the claims of teachers ${ }^{6}$ and actors ${ }^{7}$ on a salaried basis, for example, as well as active officers and directors of corporations, despite the fact that their

\footnotetext{
3 141 F. Supp. 463 (S.D.N.Y. 1956).

The pertinent portions of the collective bargaining agreement between the employer and Local 140 are the following:

"Thirty-Second: The employer hereby agrees, as long as this agreement remains in effect, to pay monthly on or before the tenth day of each month, a sum equal to $6 \%$ of the monthly gross payroll of the employees in the bargaining unit, to Local 140 Security Fund, for the purpose of financing a Security Plan for the benefit of the employees of the Employer within the bargaining unit. At the same time the Employer shall forward a report setting forth the figures upon which payment is based.

"Commencing February 15th, 1953, the Employer agrees to pay an additional onehalf $(1 / 2 \%)$ percent to the Local 140 Security Fund, the sum to be applicable to the Welfare provisions of the Security Fund, making it a total of six and one-half $(6 \% / 2 \%)$ percent.

"The employer further agrees to make the aforesaid remittances to the Local 140 Security Fund at its offices and that each monthly payment shall be based upon the grosss monthly payroll of the employees in the bargaining unit for the preceding month. ..." I 4 I F. Supp. at 465 , n. 2 .

The words of $\$ 64 \mathrm{a}$ (2) "cannot be extended by the courts to cover cases not comprehended by the statute, merely because the case in hand may be thought equally meritorious with those that are given a special status. The act does not provide that all who work for a wage of less than so much a week shall have priority. In any case where priority is asserted, the claimant must bring himself within one of the four classes specified by Congress, 'workmen, clerks, traveling or city salesmen, or servants.' "In re Estey, 6 F. Supp. 570 (S.D.N.Y. I934). Cf. in re Quackenbush, 259 Fed. 599 (D. N.J. 19r9). See also Note, 34 CHi.-KENT L. REv. 235 (1956).

In re Estey, note 5 supra.

7 "To permit a construction of the words 'workmen or servants' to include petitioner would do. violence to the clear import of the language used by Congress. These words must be construed in accordance with their common and popular meaning. . . Professional persons are not popularly considered workmen or servants." In re Paradise Catering Corp, 36 F. Supp. 974, 975 (S.D.N.Y. 1941).
} 
claims may have arisen from the performance of incidental clerical work ${ }^{8}$ or other menial tasks. ${ }^{9}$

On the other hand, once a claimant has established his identity as one of the class protected by section 64a(2), what constitutes his "wages" has been the subject of liberal construction. ${ }^{10}$ The court in Sleep Products, however, ruled, in effect, that no reasonable degree of liberality could justify the inclusion of welfare fund contributions within the scope of the priority. One articulated consideration supporting this conclusion was that since the benefits resulting from these contributions were contingent and prospective in nature, they constituted, at present, nothing more than mere expectancies of payments at some future date, with no currently commutable value, and, accordingly, fell outside the statutory prescription that the sums must be due the employee. ${ }^{11}$

While, perhaps, superficially valid, this assumption underlying the court's decision is, in fact, quite untenable in that it ignores the value of the element of immediate protection that welfare funds afford the worker. Indeed, if present security-surely an element of value-were not accorded the wage earner through such work-connected welfare plans, the accompanying threat to his personal security and well-being might compel him to acquire similar insurance coverage by other means, with a consequent reduction in his wages. ${ }^{12}$ Welfare fund constributions

. In re L. W. Birmingham \& Son Co., I F.2d 5 I I (E.D. Tenn. 1924); In re Floyd Shoe Co., 3 F. Supp. 568 (E.D.N.Y. 1 933). But managers of branch retail stores acting as clerks and possessing only limited managerial duties are entitled to priority as wage claimants. In re Pacific Co-Op. League Stores, 291 Fed. 759 (9th Cir. 1923).

" $[W]$ here a claimant has served in both supervisory and subordinate capacities, his status as a wage worker may depend upon which of his activities constituted his "principal service.". Thus, the co-owner of a tavern cannot maintain a wage priority claim, purportedly arising from his duties as a bartender, when he is neither subject to supervision nor has entered into an employment contract. In re Ko-ed Tavern, Inc., $129^{\circ}$ F.2d 806, 8o9 (3rd Cir. 1942).

10 'Liberality of construction of the term 'wages' does not justify a nullification of . the language of the statute which grants priority only to 'wages . . . due to workmen'.... The employee never had an individual or assignable proprietory interest in the contribution or to the fund of which the contribution became a part." In re Brassell, 135 F. Supp. 827,830 (N.D.N.Y. 1955). But see In re Otto, 146 F. Supp. 786 (S.D. Cal. 1956).

${ }_{11}$ Worker $A$, for example, whose monthly wages are $\$ 300$ and who receives no welfare fund protection is in no better position financially than worker $B$ who, in addition to his $\$ 275$ monthly income, also receives $\$ 25$ worth of fund benefits. Indeed, considering the tax advantage accruing to $B$ and the non-profit nature of the trust fund organization, $B$ appears to occupy the preferred position. See note 26 infra.

12 It should be readily apparent that, to the extent that a worker must secure insurance benefits by entering into a contract with a private company, his wages have been diminished in proportion to the amount expended in obtaining the necessary coverage. On the other hand, an employee who receives fringe benefits in the form of insurance is com- 
made by an employer are, then, at least constructively, additional wages so diverted as to secure something of present as well as future value to the employee. Therefore, to exclude these sums from the section $64 \mathrm{a}(2)$ priority solely on the basis of the contingent nature of the benefit they confer is inaccurately to perceive the substance of fringe benefits in general and welfare funds in particular. The result is an unwarranted dilution of an employee's compensation for which neither he nor his employer have bargained. ${ }^{\mathbf{1 3}}$

Another argument adduced to support the court's ruling that the payments to the welfare fund were not due the employee was that they were made directly to the trustees of the fund, rather than to the employees. ${ }^{14}$ This is essentially a restatement of the dogma that "the relationship between claimant and bankrupt is the true test of whether a claim is entitled to priority."15 Thus, it was reasoned that since the employer's obligation to pay the prescribed sums was not enforceable by the employees, the disputed claim was not due them. NLRB $v$. Killoren, ${ }^{10}$ a case in which the Board was held entitled to the benefits of section $64 \mathrm{a}(2)$ in seeking enforcement of a back pay order against a bankrupt employer for the benefit of certain employees, is, however,

pensated in the amount that he would otherwise be compelled to pay out of his own pocket. Thus, it would appear that in either case that portion of income set aside for insurance premium payments would be tantamount to "wages."

${ }^{13}$ Contributions to welfare funds have found increasing popularity as a means to provide the worker more compensation for his labor, and, at the same time, make such increases financially easier for the employer to bear. See note 21 infra. To preclude them from recovery by employees in bankruptcy proceedings, then, overlooks the obvious purpose of fringe benefit-type collective bargaining and limits the cmployee to a priority claim for monetary arrearages alone. Realistically, this view deprives him, in spite of the policy underlying $\S 64 a(2)$, of that part of his earned wages which is due him indirectly.

${ }_{14}$ For provisions of the collective bargaining agreement, sce note 4 supra.

${ }^{15}$ Claimants who were employed by a bankrupt milk company were denicd wage priosities because, since the'teams they used were their own and their routes were left to their discretion and choice, there was no control or direct supervision of their work by the bankrupt employer. "If the fact that these claimants in discharging their engagement performed such manual or physical labor as is usually a proper subject of hiring a workman or servant were controlling, then obviously they are workmen or servants. But that rather begs the real question, which is, What was the relation wherein they performed their work or rendered their service?" In re Footville Condensed Milk Co., 237 Fed. 136,138 (W.D. Wis. 1916). The master-servant relationship was also held to be controlling where independent contractors who sewed for a bankrupt clothing manufacturer, In re Ageloff, 40 F. Supp. 369 (S.D.N.Y. 1939), and a one-third owner of a bankrupt business who was to work without any definite arrangement with his co-owners but only as he saw fit, In re Progressive Luggage Corp., 34 F.2d 138 (2d Cir.11929), were denied priorities.

- 10122 F.2d 609 (8th Cir. 1941). Cf. Nathanson v. NLRB, 344 U.S. 25 (1952). 
relevant in this connection. ${ }^{17}$ Although the right of the NLRB there rested upon a statutory basis, ${ }^{18}$ the situation was analogous to that in Sleep Products in that in both cases a priority claim was asserted by an agency in behalf of employees who, though powerless to act individually, were the sole beneficiaries of the relief sought. While the technical right of action vests in the trustees of the fund, the actual benefit accrues to the workers. If the employees concerned had contracted individually with the employer for the fund contributions, their benefits would have been neither more nor less than they were under the trust relationship. ${ }^{19}$ Viewed in this perspective, the "relationship test" appears to be more concerned with form than substance. For, where a welfare fund is nothing more than than a convenient means of securing to employees a certain type of beneficial remuneration in exchange for their labor, the equitable right to that remuneration, as well as to all of its incidents, belongs not to the fund, but to them. By classifying the fund as a general creditor, ${ }^{20}$ then, the employees are likewise so classified to the extent of the contributions due it on their account.

The district court in Sleep Products further bolstered its conclusion with the argument that since contributions to union welfare funds are neither taxable as income ${ }^{21}$ nor deemed part of the employee's base pay

\footnotetext{
27 "The Board's status with respect to the back pay allowances was, as to the employees entitled to the benefits of the order, in the nature of a plenary trusteeship. Since the Act constituted it the only party entitled to seek enforcement, it could properly be said to hold the full legal title to the obligations which the order created, within any technical concept that might be necessary in the situation. The Board was therefore a creditor under the Bankruptcy Act, within the definition of $\S$ I (II), II U.S.C.A. $\S$ I (II), providing that "Creditor" shall include anyone who owns a debt, demand, or claim provable in bankruptcy, and may include his duly authorized agent, attorney, or proxy." "NLRB v. Killoren, supra note I6 at 6r2.

${ }_{18}$ National Labor Relations Act § I et seq. and § Io(e). 49 STAT. 449 (I935), 48 STAT. 926 (1934), 29 U.S.C. \$ 151 et seq., \$ I6o(e) (1952).

${ }^{10}$ Employees' rights as beneficiaries of collective bargaining agreements have also. been recognized under the custom or usage theory, which treats the collective bargaining agreement as creating custom or usage which may be ratified by the employee to become part of his individual contract of employment with the employer. Yazoo \& M. V. R. Co. v. Webb, 64 F.2d 902 (5th Cir. I 933); Gregg v. Starks, 188 Ky. 834, 224 S.W. 459 (1920); United States Daily Pub. Co. v. Nichols, 32 F.2d 834 (D.C. Cir. I929). See Rice, Collective Labor Agreements in American Law, 44 HARv. L. REv. 572, 581 (1930); Note, 4 SYracuse L. REv. 146 (1952).

${ }_{20}$ General creditors may be recompensed only after certain statutory priorities are satistied. For example, taxes and administration costs, in addition to wage earners' priorities, are, among others, usually paid before claims of general creditors.

${ }^{21}$ Employees are exempted from paying an income tax on "contributions by the employer to accident or health plans for compensation (through insurance or otherwise) to his employees for personal injuries or sickness." INT. REV. CODE OF ' 1954, § ro6; 68A STAT. 32 (1954), 26 U.S.C.A. \$ 106 (1955). I CCH 1956 STAND. FED. TAX REP. Iro5o. Nor can the employer's payments to the fund be taxable to the employee
} 
for the purpose of computing social security taxes, ${ }^{22}$ they, therefore, cannot be considered "wages." This rationale, in the absence of a more apposite criterion, indeed lends itself to facile acceptance: But it does not necessarily follow that provisions of the Internal Revenue Code should arbitrarily be utilized to shape the form of "wages" for the purposes of section 64a(2). "Wages," as commonly understood, are the reward of labor, the compensation paid an employee for services rendered, and they connote any material aid, whether in the form of money or anything else of value. The policy factors underlying the wage earner's priority ${ }^{23}$ would, accordingly, seem to compel a construction of the Act consistent with this common understanding.

In the Sleep Products case, the court indicated that "any basic change in the pattern of priorities should be accomplished by Congress and not by the courts."24 Indeed, in the field of analogous state legislation, there is already a perceptible trend in that direction. ${ }^{25}$ Congress, how-

on constructive receipt grounds. U.S. Treas. Reg. $118, \$ 39.42-2$ (1951). Cf. Sloane v. Commissioner of Internal Revenue, 188 F.2d 254 (6th Cir. 1951).

22 Section 3121 (a) (2) of the Federal Insurance Contributions Act provides:

"(a) Wages.-For purposes of this chapter, the term 'wages' means all remuneration for employment, including the cash value of all remuneration paid in any medium other than cash; except that such term shall not include-

(2) the amount of any payment (including any amount paid by an employer for insurance or annuities, or into a fund, to provide for any such payment) made to, or on behalf of, an employee or any of his dependents under a plan or system established by an employer which makes provision for his employees generally (or for his employees generally and their dependents) or for a class or classes of his employees (or for a class or classes of his employees and their dependents), on account of -

(A) retirement, or

(B) sickness or accident disability, or

(C) medical or hospitalization expenses in connection with sickness or accident disability, or

(D) death. ..."

68A STAT. 417 (1954), 26 U.S.C.A. \$ 3121 (a) (2) (Supp. 1956).

${ }_{23}$ "The history of the section indicates clearly that the intention thereof was to give a special protection in a limited amount to workmen who by reason of the amount of their remuneration would ordinarily be expected to depend upon their daily, weekly or monthly wage for their support and the support of their families." In re Brassell, 135 F. Supp. 827, 829. (N.D.N.Y. 1955). Cf. In re Paradise Catering Corp., 36 F. Supp. 974 (S.D.N.Y. 1941). These workmen, unable to ascertain the credit standing of their employer and forced to accept credit as it comes, can ill afford to stand as general creditors. Blessing v. Blanchard, 223 Fed. 35 (9th Cir. 1915); In re Estey, 6 F. Supp. 570 (S.D.N.Y. 1934); 3 CollieR, BANkRUPTCY 164.201 (14th ed. 1940).

$1414 \mathrm{~F}$. Supp, at 470 .

${ }^{25}$ NeW YORK DebTOR AND CReditor LAW $\$ 22$ (Supp. 1956) now includes within the defiuition of "wages or salaries," the following, inter alia: "employer contributions to or payments of insurance or welfare benefits;" and "employer contributions to pension or annuity funds."

In California, criminal sanctions have been imposed to force the employer to pay 
ever, while recognizing a grave responsibility to insure the sound operation of welfare funds ${ }^{26}$ has, as yet, indicated no like intention. Nevertheless, the absence of legislative amendment of the Bankruptcy Act does not relieve the judiciary of its duty to exercise initiative in the equitable resolution of fringe benefit problems. ${ }^{27}$

The importance of such a flexible interpretation is augmented by the probability that the courts will increasingly be confronted with priority claims based upon fringe benefits. ${ }^{28}$ This renders it all the more imperative that they recognize and give effect to the policy considerations underlying section 64a(2). In this respect, some courts have already progressed; for example, it has been held that vacation and severance pay constitute "wages" within the meaning of the section. ${ }^{29}$ Welfare fund contributions have an identical basis in a collective bargaining agreement and have, at least, as meritorious a claim to the same favorable treatment. Where fringe benefits are bargained for and received in lieu of cash wages, they should not be subjected to archaic tests but should rather be considered in the light of present-day labor conditions.

contributions to a union welfare fund by providing that wilful failure to do so is a misdemeanor. CAL. LABOR CODE $\$ 227$ (Deering, Supp. 1955).

${ }^{20}$ In the final report submitted to the Senate Committee on Labor and Welfare by its Subcommittee on Welfare and Pension Funds pursuant to S. RES. 4o, as extended by S. RES. 200 and S. RES. 232 (84th Cong.) authorizing. a study and investigation of private employer welfare and pension plans subject to collective bargaining, it was stated that the rapid and substantial growth of such plans and the use of such large tax exempt funds places upon the Government a responsibility for the protection of the beneficiaries as well as an obligation to insure the sound operation of such funds in the public interest. Unnumbered Senate Report Issued as a Committee Print, 84 th Cong., 2d Sess. 365 (April 6, 1956).

${ }^{27}$ Mr. Justice Holmes in Towne ซ. Eisner, 245 U.S. 418, 425 (1918), said: "A word is not a crystal, transparent and unchanged, it is the skin of a living thought and may vary greatly in color and content according to the circumstances and the time in which it is used." And Mr. Justice Frankfurter has cautioned against making "of law too thin a dialectic enterprise." NLRB v. Coca-Cola Bottling Co. of Louisville, 350 U.S. 264,268 (1956).

${ }^{3}$ See note 2 supra.

30 "A vacation with pay is in effect additional wages. It involves a reasonable arrangement to secure the well being of employees and the continuance of harmonious relations between employer and employee." In re Wil-Low Cafeterias, 1 I I F.2d 429, 432 (2d Cir. 1940). See also In re Kinney Aluminum Co., 78 F. Supp. 565 (S.D. Cal. 1948).

It has been held that the purpose of a severance pay agreement is to provide protection to the employee against sudden discharge and is enforceable as a wage priority, even though technically unearned, on the theory that it was mutually beneficial and "an entirely reasonable and enlightened arrangement." McCloskey v. Division of Labor, 200 F.2d 402, 403 (9th Cir. 1952). See also In re Public Ledger, Inc., I6 I F.2d 762 (3rd Cir. 1947). 